\title{
Hubungan Faktor Kapabilitas, Motivasi, dan Pendayagunaan SDM terhadap Kinerja pada Pegawai Puskesmas
}

\author{
Rahma Maulidiyah*, Sendhi Tristanti Puspitasari, Endang Sri Redjeki \\ Universitas Negeri Malang, Jl. Semarang No. 5 Malang, Jawa Timur, Indonesia \\ *Penulis korespondensi, Surel: dheamaulidia39@gmail.com
}

Paper received: 23-7-2021; revised: 13-8-2021; accepted: 20-8-2021

\begin{abstract}
Performance or individual work results in carrying out his duties according to predetermined targets. Coverage of the performance appraisal of Public Health Malang in 2019, Kendalsari Health Center has a sufficient assessment with an average value of 7.89 on the Public Health management indicator. In addition, the results of employee performance appraisals conducted by the Malang Health Office in 2017-2019 on ASN employees at Kendalsari Health Center have not increased every year. Aims to determine the related between capability, motivation, and human resource utilization factors on employee performance. This study used a cross-sectional study design with quantitative methods. The population of this research is employees at Kendalsari Public Health, Malang. The sample using purposive sampling technique. The data analysis used was ordinal regression test. The results of the research analysis showed that the variable that has a relationship with employee performance is motivation $\left(\mathrm{G}^{2}\right.$ value is 13.046$)$ because the $\mathrm{G}^{2}$ value is greater than the chi-square $\left(\mathrm{x}^{2}\right)$ table is 7,815 . Meanwhile, the capabilities (G2 is 0.823 ) and the utilization of human resources $\left(\mathrm{G}^{2}\right.$ is 0.0$)$ were smaller than the chi-square $\left(\mathrm{x}^{2}\right)$. Thus, the most important variable is motivation with value (odd ratio is 13.45).
\end{abstract}

Keywords: capability; motivation; utilization of human resources; employee performance

\begin{abstract}
Abstrak
Kinerja atau hasil kerja individu saat melaksanakan tugas yang sesuai dengan target ataupun kriteria yang sudah ditentukan. Berdasarkan cakupan penilaian kinerja Puskesmas di Kota Malang tahun 2019 Puskesmas Kendalsari memiliki penilaian yang masih cukup dengan nilai rata-rata 7,89 pada indikator manajemen Puskesmas. Selain itu, hasil penilaian kinerja pegawai yang telah dilakukan oleh Dinas Kesehatan Kota Malang tahun 2017-2019 pada pegawai ASN di Puskesmas Kendalsari belum meningkat setiap tahunnya. Berdasarkan studi pendahuluan menunjukkan bahwa kinerja pegawai di Puskesmas Kendalsari masih rendah. Tujuan penelitian untuk mengetahui hubungan faktor kapabilitas, motivasi, serta pendayagunaan SDM terhadap kinerja pegawai Puskesmas Kendalsari Kota Malang. Desain studi penelitian ini yakni cross-sectional menggunakan metode kuantitatif. Populasinya yaitu pegawai di Puskesmas Kendalsari Kota Malang. Penentuan sampel dengan teknik purposive sampling. Analisis datanya menggunakan uji regresi ordinal. Hasil analisis penelitian didapatkan variabel yang memiliki hubungan dengan kinerja pegawai adalah motivasi (nilai $\mathrm{G}^{2}$ adalah 13,046$)$ dikarenakan nilai $\mathrm{G}^{2}$ lebih besar dari chi-square $\left(\mathrm{x}^{2}\right)$ tabel adalah 7,815 . Sedangkan, kapabilitas $\left(\mathrm{G}^{2}\right.$ adalah 0,823$)$ dan pendayagunaan SDM $\left(\mathrm{G}^{2}\right.$ adalah 0,0$)$ lebih kecil dari chi-square $\left(\mathrm{x}^{2}\right)$ tabel yang menunjukkan tidak ada hubungan. Sehingga, variabel yang paling berhubungan dengan kinerja pegawai yakni motivasi dengan nilai (odd ratio adalah 13,45).
\end{abstract}

Kata kunci: kapabilitas; motivasi; pendayagunaan SDM; kinerja pegawai

\section{Pendahuluan}

Riset Kesehatan Dasar tahun 2018 menunjukkan proporsi pengetahuan masyarakat terkait kemudahan akses ke Puskesmas, Pustu, Pusling, dan Bidan Desa berdasarkan tempat tinggal dari segi jenis kendaraan, waktu yang ditempuh, serta biaya transportasi ke fasilitas kesehatan di Indonesia yaitu 39.2 mudah, 31.8 sulit, 29.0 sangat sulit. Sedangkan, pengetahuan 
masyarakat terkait hal tersebut berdasarkan Provinsi, proporsi tertinggi diduduki oleh Bali dan terendah Papua. Sedangkan, Jawa Timur berada pada urutan ke-9 (Litbang Kementerian Kesehatan RI, 2018).

Sebagai konsekuensi tuntutan masyarakat, pegawai harus memberikan pelayanan yang terbaik. Khususnya, bagi petugas pelayanan kesehatan harus berkontribusi besar dalam meningkatkan kinerjanya sehingga berdampak positif bagi kualitas hidup dan kesejahteraan pasien. Sehingga, diharapkan setiap pegawai mampu mengidentifikasi kualitas kerja untuk dimonitor, diperbaiki, serta ditingkatkan terus-menerus (Hasmoko, 2014). Selain itu, dukungan dari pimpinan juga menjadi kunci pegawai untuk meningkatkan kinerjanya.

Puskesmas Kendalsari yakni salah satu FKTP Kota Malang berdiri sejak tahun 1984. Wilayah kerja Puskesmas ini meliputi tiga kelurahan yakni Kelurahan Lowokwaru, Kelurahan Tulusrejo dan Kelurahan Jatimulyo. Puskesmas ini memiliki beberapa unit pelayanan yang dapat menunjang pasien dan sudah berpedoman pada peraturan perundang-undangan (Puskesmas kendalsari, 2020).

Berdasarkan penilaian kinerja Puskesmas Kota Malang tahun 2019, yang dilakukan oleh Dinas Kesehatan, kinerja Puskesmas Kendalsari tergolong cukup baik. Penilaian kinerja Puskesmas Kendalsari dengan indikator manajemen Puskesmas dengan nilai rata-rata 7,89 tergolong dalam penilaian cukup. Penilain kinerja dalam indikator manajemen Puskesmas dikatakan baik apabila nilai rata-rata $\geq 8,5$. Sedangkan, penilaian kinerja Puskesmas Kendalsari dalam indikator upaya kesehatan dan program memiliki nilai rata-rata 75,67 yang tergolong dalam penilaian cukup. Penilaian kinerja dalam indikator upaya kesehatan dan program dapat dikatakan baik jika nilai rata-rata $\geq 91$. Sehingga, kinerja Puskesmas Kendalsari masih dikatakan cukup pada tahun 2019 (Dinas Kesehatan Kota Malang, 2020).

Berdasarkan studi pendahuluan, peneliti memperoleh data kepuasan masyarakat tahun 2019 di Puskesmas Kendalsari Kota malang yang diukur menggunakan kuesioner dan menyebutkan bahwa dari beberapa indikator dalam kuesioner tersebut, ada satu indikator yang nilainya paling rendah sebesar 3,19 tentang waktu penyelesaian pelayanan yang diberikan kepada masyarakat. Indikator waktu penyelesaian pelayanan meliputi ketepatan waktu berlangsungnya pelayanan, kejelasan informasi mengenai waktu penyelesaian pelayanan dan kesesuaian waktu penyelesaian layanan sesuai dengan yang dijanjikan. Rendahnya indikator tersebut, berarti rendahnya koordinasi antara satu pegawai, dengan pegawai yang lainnya dan pelayanan yang diberikan belum bisa memenuhi standart yang sudah ditentukan (Puskesmas kendalsari, 2020).

Berdasarkan beberapa permasalahan yang terjadi di Puskesmas Kendalsari, apabila dikaitkan dengan kinerja individu kondisi seperti ini dapat menurunkan kinerja pegawai. Menurut teori kinerja Robbins (2006) menjelaskan bahwa kinerja pegawai merupakan fungsi interaksi antara kapabilitas, motivasi, dan pendayagunaan SDM (Kadir, Abdul \& Machasin, 2014). Sehingga, perlu dilaksanakan penelitian untuk mengetahui "Hubungan Faktor Kapabilitas, Motivasi, dan Pendayagunaan SDM Terhadap Kinerja Pada Pegawai Puskesmas."

\section{Metode}

Penelitian ini termasuk penelitian analitik observasional, menggunakan desain studi cross-sectional dan metode kuantitatif. Variabel terikatnya yaitu kinerja pegawai, dan variabel bebasnya yaitu kapabilitas, motivasi, dan pendayagunaan SDM. Sebelum penelitian dilakukan, 
peneliti melakukan survei atau pengamatan langsung kinerja pegawai. Penelitian ini dilaksanakan di Puskesmas Kendalsari Kota Malang pada bulan Oktober-November 2020.

Populasinya yaitu seluruh pegawai di Puskesmas Kendalsari Kota Malang 50 orang, yang terdiri dari 42 pegawai PNS dan 8 pegawai bukan PNS. Penentuan sampel dilakukan dengan teknik purposive sampling, yaitu pengambilan sampel yang menyebutkan kriteria tertentu (Kadir, Abdul \& Machasin, 2014). Peneliti menentukan sampel berdasarkan kriteria inklusi yakni kriteria umum subjek penelitian yang harus dipenuhi oleh seorang populasi yang nantinya diambil untuk sampel, dan kriteria eksklusi yakni anggota populasi yang tidak bisa dijadikan sampel penelitian (Hidayat \& Hayati, 2019). Kriteria inklusinya yaitu pegawai ASN di Puskesmas Kendalsari Kota Malang, sedangkan kriteria eksklusinya yaitu pegawai non-ASN di Puskesmas Kendalsari Kota Malang. Sehingga, sampel yang akan diteliti adalah pegawai ASN di Puskesmas Kendalsari Kota Malang yang berjumlah 42 orang dan 8 orang pegawai non-ASN tidak diteliti karena tidak termasuk dalam kriteria inklusi.

Instrumen penelitian menggunakan kuesioner yang terdiri dari pertanyaan terkait yang nantinya diisi oleh responden, instrumen yakni salah satu cara mengumpulkan data yang sangat efisien (Widi, 2015). Agar instrumen penelitian valid, maka harus diuji validitas dan uji reliabilitas. Pertanyaan disebut valid jika $r$ hitung $>r$ tabel dengan signifikansi 0,05 atau 95\% (sig 2-tailed) dengan nilai $r$ tabel $(d f=N-2)$ yaitu 0,3610. Pertanyaan dikatakan reliabel apabila nilai Alfa cronbach $\geq 0,6$ serta pertanyaan dinilai tidak reliabel apabila Alfa cronbach < 0,6 dengan taraf signifikansi 0,05 atau 95\% (sig 2-tailed) (Wahyudi, 2017). Kuesioner penelitian ini sudah melewati tahap uji etik dengan nomor reg.No.:035/KEPKPOLKESMA/2021.

Data yang dihasilkan berasal dari data primer yakni, penyebaran kuesioner serta data sekundernya yakni, penilaian kinerja pegawai tahun 2017-2019, penilaian kinerja Puskesmas Kendalsari tahun 2019 dan kepuasan pasien terhadap Puskesmas Kendalsari tahun 2019. Teknik pengolahan data yakni pengeditan data untuk melengkapi ataupun menghilangkan kesalahan pada data mentah, pengkodean data dan transformasi data, serta tabulasi data dengan cara membuat tabel sesuai dengan kebutuhan analisis (Hilman, 2017). Sedangkan, teknik penyajian data menggunakan tabel dalam bentuk angka (Wahyuni, 2015).

Analisis data pada penelitian ini melalui tiga tahapan dengan bantuan program IBM statistik SPSS 22 yakni, univariat yang dilakukan untuk mengetahui distribusi frekuensi variabel bebas dan variabel terikat (Hermawati, N. Ayu Gustia, 2018)., bivariat dilakukan untuk mencari tahu hubungan antara variabel bebas terhadap variabel terikat dengan uji regresi logistik ordinal sederhana (Yusuf, 2014), dan analisis multivariat yang digunakan sebagai analisis secara simultan variabel bebas yang dominan terhadap variabel terikat (Wustqa et al., 2018). Alur penelitian ini yaitu, membuat rumusan masalah lalu mencari literatur yang berkaitan dengan masalah sebagai dasar penguat permasalahan. Kemudian menentukan kerangka teori atau kerangka konsep, menentukan desain studi, menentukan populasi dan sampel, lalu menyusun instrumen digunakan dalam penelitian. Sehingga, proposal penelitian sudah tersusun dan mengurus perizinan penelitian untuk mengambil data. Selanjutnya, data yang sudah diperoleh diolah dan dianalisis kemudian menginterpretasi data serta membuat kesimpulan hasil penelitian dan memberikan saran. 


\section{Hasil dan Pembahasan}

Responden dalam penelitian ini adalah pegawai ASN Puskesmas Kendalsari sebanyak 42 orang. Usia responden setelah dikelompokkan yaitu 21-30 tahun sejumlah 14 orang, 31-40 tahun sejumlah 14 orang, dan 51-60 tahun sejumlah 6 orang. Jumlah pegawai ASN Puskesmas Kendalsari yakni perempuan 34 orang serta pria sebanyak 8 orang. Pendidikan terakhir pada pegawai ASN Puskesmas Kendalsari yakni 4 orang lulusan SMA, 22 orang lulusan Diploma, dan 16 orang lulusan Sarjana. Selanjutnya, untuk jabatan pegawai ASN Puskesmas Kendalsari yaitu dokter gigi 3 orang, 1 orang KA Subag TU, perawat 7 orang, dokter umum 3 orang, 1 orang asist. apoteker, 1 orang sanitarian, 3 orang nutrisionis, penata labkes 1 orang, 11 orang bidan, 2 orang perawat gigi, pengadministrasian umum 4 orang, pengemudi 1 orang, rekam medic 1 orang, dan petugas keamanan 3 orang. Lalu, rentang lama bekerja pegawai ASN Puskesmas Kendalsari yakni sebanyak 18 orang bekerja pada rentang 1-5 tahun dan sebanyak 3 orang masih bekerja kurang dari 1 tahun.

\subsection{Hubungan Antara Kapabilitas $\left(\mathrm{X}_{1}\right)$ terhadap Kinerja Pegawai di Puskesmas Kendalsari Kota Malang (Y)}

Tabel 1. Hasil Uji Regresi Logistik Ordinal Kapabilitas Terhadap Kinerja Pegawai di Puskesmas Kendalsari Kota Malang

\begin{tabular}{lccc}
\hline \multicolumn{1}{c}{ Variabel } & Koefisien Estimate & Uji G $^{\mathbf{2}}$ & Koefisien Korelasi (r) \\
\hline Kinerja & $-0,657$ & & \\
Kapabilitas & 18,705 & 0,823 & $-0,110$ \\
\hline
\end{tabular}

Hasil uji analisis regresi logistik ordinal sederhana didapatkan nilai $\mathrm{G}^{2}$ sebesar 0,823 kurang dari chi-square tabel 7,815 dimana, keputusan uji yang diperoleh adalah $\left(\mathrm{H}_{0}\right)$ gagal ditolak, yakni tidak ada hubungan kapabilitas terhadap kinerja pegawai di Puskesmas Kendalsari Kota Malang. Selanjutnya persamaan model regresi logistik ordinal sederhana yang terbentuk sesuai dengan rumus berikut.

$Y=a+b_{1} x_{1}$

$Y=0,657-18,705\left(x_{1}\right)$

Tanda (-) pada nilai $b_{1}$ menunjukkan hubungan negatif, yang berarti semakin besar kapabilitas maka kinerja pegawai akan turun dan sebaliknya. Koefisien korelasi ( $\mathrm{r}$ ) sebesar 0,110 kurang dari $r$ tabel 0,3044 dengan tingkat signifikansi $(\alpha)$ sebesar 0,05 yang berarti kekuatan hubungan sangat lemah antara kapabilitas dengan kinerja.

Kinerja yakni peraihan hasil kerja seseorang yang diperoleh sebagai prestasi kerja yang sesuai dengan pencapaian yang telah ditentukan (Widi, 2015). Kinerja pegawai juga dapat diidentifikasi sebagai fungsi interaksi antara kapabilitas, motivasi, dan pendayagunaan SDM (Kadir, Abdul \& Machasin, 2014). Kapabilitas merupakan keterampilan maupun kecakapan yang dimiliki oleh setiap seseorang untuk menyelesaikan suatu pekerjaan dan memanfaatkan kesempatan untuk mencapai tujuan yang telah ditentukan (Usman, 2016). Semakin tinggi kapabilitas pegawai maka semakin tinggi kinerja yang didapatkan, dan sebaliknya.

Setelah dilakukan analisis, hasil analisis hubungan dihasilkan bahwa kapabilitas tidak ada hubungan terhadap kinerja pegawai Puskesmas Kendalsari Kota Malang. Sehingga, 
penelitian ini tidak sejalan dengan penelitian Usman (2016) menunjukkan adanya hubungan kapabilitas terhadap kinerja nakes di Puskesmas Lappade (Usman, 2016). Selain itu, Marsita dkk., (2015) juga menjelaskan adanya hubungan antara kapabilitas terhadap kinerja nakes di Puskesmas Lambunu 2 (Marsita., Sudirman., 2015). Setiap pegawai mempunyai peran dalam meraih kinerja yang maksimal, hal ini bisa diraih jika petugas berada pada posisi yang sesuai dengan kapabilitas yang dimilikinya. Hal ini sesuai dengan job description serta job spesification dan berpedoman terhadap prinsip "The right man on the right place and the right man behind the job" (Fadilah, 2014).

\subsection{Hubungan Motivasi $\left(\mathrm{X}_{2}\right)$ terhadap Kinerja Pegawai Puskesmas Kendalsari Kota Malang (Y)}

Tabel 2. Hasil Uji Regresi Logistik Ordinal Motivasi Terhadap Kinerja Pegawai di Puskesmas Kendalsari Kota Malang

\begin{tabular}{lccc}
\hline \multicolumn{1}{c}{ Variabel } & Koefisien Estimate & Uji G $^{\mathbf{2}}$ & Koefisien Korelasi (r) \\
\hline Kinerja & $-1,992$ & & \\
Motivasi & $-2,599$ & 13,046 & 0,549 \\
\hline
\end{tabular}

Hasil analisis uji regresi logistik ordinal sederhana didapatkan nilai $\mathrm{G}^{2}$ sebesar 13,046 kurang dari chi-square tabel 7,815 dimana, keputusan uji yang diperoleh adalah $\left(\mathrm{H}_{0}\right)$ ditolak sehingga, ada hubungan antara motivasi terhadap kinerja pegawai di Puskesmas Kendalsari Kota Malang. Selanjutnya persamaan model regresi logistik ordinal sederhana yang terbentuk sesuai dengan rumus berikut.

$Y=a+b_{2} x_{2}$

$Y=1,992+2,599\left(x_{2}\right)$

Tanda $(+)$ pada $b_{2}$ menunjukkan hubungan positif yang berarti, tingginya motivasi maka, kinerja pegawai bisa meningkat. Koefisien korelasi (r) hitung 0,549 lebih besar dari $r$ tabel yakni 0,3044 dengan tingkat signifikansi $(\alpha)$ sebesar 5\% atau 0,05 menunjukkan kekuatan hubungan sedang antara motivasi terhadap kinerja pegawai.

Motivasi yaitu perasaan yang mendorong seseorang melakukan pekerjaan sesuai yang diinginkan dan berpengaruh pada lingkungan kerjanya (Mandagi, dkk., 2015). Apabila pegawai memiliki motivasi yang baik, maka kinerjanya akan meningkat. Sikap positif seseorang dalam bekerja dapat menjadikan motivasi dan kebalikannya jika seseorang memiliki sifat kurang baik maka motivasi kerjanya akan rendah (Natasya., 2014).

Hasil analisis hubungan pada penelitian ini menyatakan bahwa, adanya hubungan motivasi terhadap kinerja pegawai Puskesmas Kendalsari Kota Malang. Sejalan dengan Natasya., dkk (2014) yang menyatakan terdapat hubungan motivasi terhadap kinerja pegawai di Puskesmas Ranotna (Natasya., 2014). Dalam penelitiannya, juga dijelaskan bahwa tingginya motivasi akan sebanding dengan kenaikan kinerja individu. 


\subsection{Hubungan Antara Pendayagunaan SDM $\left(X_{3}\right)$ terhadap Kinerja Pegawai di Puskesmas Kendalsari Kota Malang (Y)}

Tabel 3. Hasil Uji Regresi Logistik Ordinal Pendayagunaan SDM Terhadap Kinerja Pegawai di Puskesmas Kendalsari Kota Malang

\begin{tabular}{lccc}
\hline \multicolumn{1}{c}{ Variabel } & Koefisien Estimate & Uji G $^{\mathbf{2}}$ & Koefisien Korelasi (r) \\
\hline Kinerja & $-0,639$ & & \\
Pendayagunaan SDM & 1,387 & 0,0 & 0,0 \\
\hline
\end{tabular}

Hasil analisis uji regresi logistik ordinal sederhana didapatkan nilai $\mathrm{G}^{2}$ sebesar 0,0 kurang dari chi-square tabel 7,815 dimana, keputusan uji yang diperoleh adalah $\left(\mathrm{H}_{0}\right)$ gagal ditolak berarti tidak ada hubungan pendayagunaan SDM terhadap kinerja pegawai di Puskesmas Kendalsari Kota Malang. Selanjutnya persamaan model regresi logistik ordinal sederhana yang terbentuk sesuai rumus berikut.

$Y=a+b_{3} x_{3}$

$Y=0,639+1,387\left(x_{3}\right)$

Tanda (-) pada nilai $b_{3}$ menunjukkan hubungan negatif yang berarti, semakin besar pendayagunaan SDM maka kinerja pegawai akan turun dan sebaliknya. Koefisien korelasi (r) 0,0 kurang dari nilai $r$ tabel 0,3044 dengan tingkat signifikansi $(\alpha)$ 0,05 berarti kekuatan hubungan sangat lemah antara pendayagunaan SDM dengan kinerja pegawai.

Pendayagunaan sumber daya manusia (SDM) merupakan sebuah potensi tenaga kerja yang terlibat dalam pekerjaan untuk mendapatkan hasil kerja maksima (Bertan, Dundu, \& Mandagi, 2016). Apabila sumber daya manusia dikembangkan akan berpengaruh pada perilaku individu maupun kelompok yang bertujuan untuk mencapai organisasi yang diinginkan. Setiap individu berhak memiliki kesempatan untuk mengembangkan dirinya dan memperluas pengalaman kerja sesuai dengan job-description (Marsita., Sudirman., 2015).

Berdasarkan hasil analisis hubungan, dihasilkan uji yang menunjukkan bahwa tidak ada hubungan pendayagunaan SDM terhadap kinerja pegawai Puskesmas Kendalsari Kota Malang. Tidak sejalan dengan penelitian Wijayanti dan Nuraini (2018) menunjukkan adanya hubungan pendayagunaan SDM terhadap kinerja pegawai dalam penelitiannya, serta menyatakan bahwa faktor pendayagunaan SDM merupakan faktor yang berpengaruh dalam kinerja pegawai (Wijayanti \& Nuraini, 2018). Selain itu, Djestawana (2014) dalam penelitiannya menunjukkan bahwa terdapat hubungan pendayagunaan SDM terhadap kinerja pegawai (Djestawana, 2014).

Rendahnya faktor pendayagunaan SDM di Puskesmas Kendalsari yakni job description seorang pegawai yang tidak sesuai dengan kapabilitas yang dimiliki. Sebaliknya, apabila faktor pendayagunaan tinggi berarti job description seorang pegawai sudah dianggap sama dengan kapabilitas serta keahlian yang dimilikinya. Posisi pegawai harus sesuai dengan job description dengan prinsip "The right man on the right place an the right man behind the job" (Fadilah, 2014). Menempatkan posisi pegawai pada posisi yang sesuai, dalam pekerjaan akan mempengaruhi kualitas kinerjanya . 
Sport Science and Health, 3(8), 2021, 586-594

\subsection{Variabel yang Paling Berhubungan dengan Kinerja Pegawai di Puskesmas Kendalsari Kota Malang}

Tabel 4. Hasil Uji Regresi Logistik Ordinal Variabel yang Paling Dominan dengan Kinerja Pegawai di Puskesmas Kendalsari Kota Malang

\begin{tabular}{lcccccc}
\hline Variabel & Estimate & $\boldsymbol{R}$-Square & Uji G $^{2}$ & Sig & $\boldsymbol{r}$ & Odd ratio \\
\hline Kinerja & $-1,992$ & & & & & \\
Motivasi & $-2,599$ & & & 0,001 & 0,549 & 13,45 \\
Constant & & 0,371 & 13,046 & & & \\
\hline
\end{tabular}

Setelah memasukkan ketiga variabel faktor kinerja didapatkan satu variabel paling berpengaruh dengan kinerja pegawai di Puskesmas Kendalsari Kota Malang yaitu motivasi $\left(\mathrm{X}_{2}\right)$. Berdasarkan hasil analisis uji regresi logistik ordinal berganda diketahui nilai $\mathrm{G}^{2}$ sebesar 13,046 lebih tinggi dari chi-square tabel 7,815 dimana, keputusan uji yang yakni $\left(\mathrm{H}_{0}\right)$ ditolak sehingga ada hubungan faktor kinerja motivasi $\left(\mathrm{X}_{2}\right)$ dengan kinerja $(\mathrm{Y})$ pegawai Puskesmas Kendalsari Kota Malang. Hasil dari uji regresi logisitik ordinal sederhana diperoleh hasil $p$ value kurang dari 0,05 yakni sebesar 0,001 pada variabel motivasi $\left(\mathrm{X}_{2}\right)$. Disimpulkan bahwa terdapat hubungan antara motivasi terhadap kinerja pegawai Puskesmas Kendalsari Kota Malang.

Selanjutnya persamaan model regresi logistik ordinal sederhana dapat ditentukan, persamaan model regresi logistik ordinal sederhana yang terbentuk rumus berikut.

$Y=a+b_{2} x_{2}$

$Y=1,992+2,599\left(x_{3}\right)$

Tanda $(+)$ pada $b_{2}$ menunjukkan hubungan positif yang berarti, tingginya motivasi maka kinerja akan meningkat dan kebalikannya. Koefisien korelasi (r) hitung 0,549 lebih besar dari nilai $r$ tabel 0,3044 dengan tingkat signifikansi $(\alpha)$ sebesar $5 \%$ yang berarti kekuatan hubungan sedang motivasi terhadap kinerja pegawai. Kemudian didapatkan juga nilai $R$-square $\left(\mathrm{R}^{2}\right)$ 0,371 menunjukkan variabel bebas yaitu motivasi $\left(\mathrm{X}_{2}\right)$ dalam menjelaskan variabel terikat berupa kinerja (Y) pegawai di Puskesmas Kendalsari Kota Malang 0,371 atau 37,1\% dan didapatkan $62,9 \%$ faktor lain yang menunjukkan variabel terikat. Nilai odd ratio variabel motivasi sebesar 13,45. Artinya, terdapat peningkatan kecenderungan sebesar 13,45 kali motivasi terhadap kinerja pegawai. Semakin baik motivasi maka kinerja pegawai dapat meningkat sebesar 13,45 kali.

Variabel yang paling berhubungan pada penelitian ini yaitu motivasi. Semakin meningkatnya motivasi pegawai, juga dapat meningkatkan kinerja pegawai sebesar 13,45 kali dibanding tanpa adanya peningkatan motivasi. Sejalan dengan penelitian yang dilaksanakan oleh Mandagi dkk., (2015) menyebutkan bahwa motivasi baik kemungkinan 6,98 kali menunjukkan kinerja baik dari pada tanpa adanya motivasi (Mandagi et al., 2015). Lalu, Primelia dan Mudayana (2014) menyebutkan bahwa motivasi yang tinggi kemungkinan 2,852 kali membuat kinerja tinggi dibanding tanpa adanya motivasi (Primelia \& Mudayana, 2014). Sehingga, dalam meraih hasil kerja yang maksimal dibutuhkan motivasi dari pribadi seseorang untuk meraih tujuan yang sudah ditentukan. Bentuk yang memotivasi pegawai di Puskesmas Kendalsari yakni pegawai mendapatkan tambahan tunjangan penghasilan, pejabat mendapat pinjaman kendaraan bermotor selama dinas, dan selama pandemi Covid-19 pegawai di 
Puskesmas Kendalsari mendapat makan siang setiap hari Senin - Kamis (Puskesmas kendalsari, 2020).

\section{Simpulan}

Berdasarkan hasil analisis, disimpulkan bahwa tidak ada hubungan faktor kapabilitas dan pendayagunaan SDM terhadap kinerja pegawai di Puskesmas Kendalsari Kota Malang. Serta, terdapat hubungan faktor motivasi dengan kinerja pegawai Puskesmas Kendalsari Kota Malang. Dapat ditunjukkan bahwa, tingginya motivasi kerja pada pegawai sehingga semakin tinggi kinerjanya. Berdasarkan hasil serta pembahasan yang sudah dilaksanakan, peneliti mengusulkan saran bagi Dinas Kesehatan Kota Malang, Puskesmas Kendalsari Kota Malang, dan bagi peneliti selanjutnya. Bagi DInas Kesehatan Kota Malang, perlu meningkatkan kapabilitas dan pendayagunaan SDM melalui program pengembangan SDM pegawai Puskesmas di Kota Malang, serta memberikan evaluasi dan masukan pada kinerja pegawai di seluruh Puskesmas khususnya yang penilaian kinerjanya rendah. Bagi Puskesmas Kendalsari, untuk meningkatkan kinerja pegawai adalah motivasi karena dukungan dari pihak atasan terkait motivasi pegawai sangat diperlukan untuk mengembangkan karier dan meningkatkan kinerja pegawai. Lalu, peneliti selanjutnya diharapkan menambah jumlah sampel, dan melakukan pembaruan analisis sesuai dengan data yang dimiliki.

\section{Daftar Rujukan}

Bertan, C. V., Dundu, A. K. T., \& Mandagi, R. J. M. (2016). Pengaruh Pendayagunaan Sumber Daya Manusia (Tenaga kerja) Terhadap Hasil Pekerjaan (Studi Kasus Perumahan Taman Mapanget Raya (Tamara). Sipil Statik, 4(1), 13-20. from https://ejournal.unsrat.ac.id/index.php/jss/article/view/10727/10309

Dinas Kesehatan Kota Malang. (2020). Puskesmas Kendalsari. Retrieved September 17, 2020, from https://dinkes.malangkota.go.id/unit-pelaksana-teknis/puskesmas-kendalsari/

Djestawana, I. G. G. (2014). Pengaruh Pengembangan Organisasi , Kepemimpinan , Jenjang Karir terhadap Kepuasan Kerja dan Kinerja Pegawai Puskesmas. Jurnal Kesehatan Masyarakat Nasional, 6, 261-266.

Fadilah, A. (2014). Pengaruh Penempatan Pegawai Terhadap Kinerja (Studi Pada Pegawai Sekretariat Daerah Kabupaten Gresik). Jurnal Administrasi Publik Mahasiswa Universitas Brawijaya, 1(5), 847-852.

Fatkhiyah, N. (2015). Motivasi, Kualitas Supervisi Dan Kepatuhan Bidan Dalam Mendeteksi Preeklampsia. Jurnal Kesehatan Masyarakat, 10(2), 195.

Fitri, M., Hardisman, H., \& Ibrarodes, I. (2019). Hubungan Budaya Organisasi dengan Kinerja Pegawai RSUD Mukomuko Tahun 2017. Jurnal Kesehatan Andalas, 8(2), 305. https://doi.org/10.25077/jka.v8.i2.p305-314.2019

Hasmoko, E. V. (2014). Analisis Faktor-Faktor Yang Mempengaruhi Kinerja Klinis Perawat Berdasarkan Penerapan Sistem Pengembangan Manajemen Kinerja Klinis (Spmkk) Di Ruang Rawat Inap. Universitas Diponegoro Semarang, 1-130.

Hermawati, N. Ayu Gustia, Y. D. (2018). Jurnal Kesehatan Saintika Meditory Jurnal Kesehatan Saintika Meditory. Jurnal Kesehatan Saintika Meditory Jurnal Kesehatan Saintika Meditory, 1(August), 79-88. Retrieved from http://jurnal.syedzasaintika.ac.id/index.php/meditory/article/view/244

Hidayat, R., \& Hayati, H. (2019). Pengaruh Pelaksanaan Sop Perawat Pelaksana Terhadap Tingkat Kecemasan Pasien Di Rawat Inap Rsud Bangkinang. Jurnal Ners, 53(9), 1689-1699.

Hilman, I. (2017). Pengolahan dan analisis data penelitian. Retrieved from https://www.academia.edu/30892425/PENGOLAHAN_DAN_ANALISIS_DATA_PENELITIAN

Kadir, Abdul, M., \& Machasin, D. (2014). Jurnal Ekonomi Volume 22, Nomor 2 Juni 2014. 22,1-17.

Kasim, F., \& Ginting, A. (2019). Pegawai di Puskesmas Juhar Kecamatan Juhar Kabupaten Karo. 2(1), 75-83.

Kementerian Kesehatan RI Badan Penelitian dan Pengembangan. (2018). Hasil Utama Riset Kesehatan Dasar. Kementrian Kesehatan Republik Indonesia, 1-100. https://doi.org/1 Desember 2013 
Mandagi, F. M., Umboh, J. M. L., \& Rattu, J. A. M. (2015). Analisis Faktor - Faktor Yang Berhubungan Dengan Kinerja Perawat Dalam Menerapkan Asuhan Keperawatan Di Rumah Sakit Umum Bethesda Gmim. Jurnal E-Biomedik, 3(3). https://doi.org/10.35790/ebm.3.3.2015.10479

Marsita., Sudirman., H. (2015). Faktor-Faktor yang Berhubungan dengan Kinerja Petugas Kesehatan di Puskemas Lambunu 2 Kabupaten Parigi Moutong. 53(9), 477-486.

Natasya., dkk. (2014). Hubungan Antara Motivasi Kerja dengan Kinerja Pegawai Puskesmas Ranotana Weru Kecamatan Wanea Kota Manado. 1-8.

Primelia, A., \& Mudayana, A. A. (2014). Hubungan Motivasi Kerja dengan Kinerja Tenaga Kesehatan di Seluruh Puskesmas Kota Yogyakarta. Universitas Ahmad Dahlan, 1-8.

Puskesmas kendalsari. (2020). Profil Puskesmas Kendalsari - Puskesmas Kendalsari. Retrieved September 17, 2020, from https://puskkendalsari.malangkota.go.id/profil-puskesmas-kendalsari/

Usman. (2016). Analisis Kinrja Tenaga Kesehatan Pada Puskesmas Lapadde Kota Parepare Performance Analysis of Health Community in Health Centers Lapadde Parepare City. Jurnal Mkmi, 12(1), 21-28. Retrieved from https://media.neliti.com/media/publications/212774-analisis-kinerja-tenagakesehatan-pada-p.pdf

Wahyudi, R. (2017). Uji Validitas Dan Reliabilitas Dengan Pendekatan Konsistensi Internal Kuesioner Pembukaan Program Studi Statistika Fmipa Universitas Bengkulu. FMIPA Universitas Bengkulu Jl. W.R. Supratman Bengkulu 38123, 1(1), 1-22. Retrieved from http://sigitnugroho.id/e-Skripsi/0805 Uji Validitas Dan Reliabilitas Dengan Pendekatan Konsistensi Internal Kuesioner Pembukaan Program Studi Statistika Fmipa Universitas Bengkulu .pdf

Wahyuni, S. (2015). Menyajikan data penelitian. Jurnal Penelitian, (April), 1-6. Retrieved from https://med.unhas.ac.id/kedokteran/wp-content/uploads/2015/04/M.Penelitian_Menyajikan-datapenelitian_SWahyuni2015.pdf

Widi, R. (2015). Uji Validitas Dan Reliabilitas Dalam Penelitian Epidemiologi Kedokteran Gigi. Stomatognatic, $8(1), 27-34$.

Wijayanti, R. A., \& Nuraini, N. (2018). Kinerja petugas program kesehatan ibu di puskesmas ( analysis of motivation , opportunity, ability and performance maternal health programs in puskesmas ). Jurnal Manajemen Informasi Kesehatan Indonesia, 6, 7-13.

Wustqa, D. U., Listyani, E., Subekti, R., Kusumawati, R., Susanti, M., Matematika, J. P., \& Uny, F. (2018). Analisis Data Multivariat Dengan Program R Multivariate Data Analysis Using R Program. Pengabdian Masyarakat MIPA Dan Pendidikan MIPA, 2(2), 83-86.

Yusuf, M. A. N. (2014). Analisis Data Multivariat Konsep Dan Aplikasi Regresi Linear Ganda. Modul Terapan. 